\title{
Military Architecture and Mathematics
}

\author{
Marco Giorgio Bevilacqua
}

Published online: 4 November 2014

(C) Kim Williams Books, Turin 2014

\begin{abstract}
NNJ guest editor Marco Giorgio Bevilacqua introduces the papers in the special issue of the Nexus Network Journal dedicated to Military Architecture and Mathematics.
\end{abstract}

Keywords Military architecture $\cdot$ Fortifications · Geometry

The use of firearms in the warfare techniques from the early fifteenth century forward triggered a progressive and radical renovation of the systems of fortification, which until then had remained essentially unchanged since antiquity. ${ }^{1}$ High walls, towers and moats, elements of an archetype based on the plunging defence, quickly showed their inadequacy to resist the new techniques of attack, the purpose of which was to breach the walls, rather than climb them.

A very lively season started; supported by the cultural spirit of the Italian Renaissance, in little more than one century it led to the conception of a new system of urban and territorial defences.

Fortresses of the first half of the fifteenth century, even if still tied to the medieval tradition, were already characterized by a first gradual geometric regularization of their structure, with all the elements placed and proportioned according to rules of optical control. In the experimentations that followed, the principle of the flanking defence was recovered from the classical tradition and innovatively adopted as a key element of the design. With the contributions of many Renaissance architects-

\footnotetext{
${ }^{1}$ In the 8000 B.C., Jericho was defended by walls, towers and a moat; in the Bronze Age, Chalandriani in Syros was fortified with circular walls and semi-circular towers (Santoro 1996: X).
}

M. G. Bevilacqua $(\bowtie)$

DESTeC, Dipartimento di Ingegneria dell'Energia, dei Sistemi, del Territorio e delle Costruzioni, Università di Pisa, Via Diotisalvi, 2, 56126 Pisa, Italy

e-mail: mg.bevilacqua@ing.unipi.it 
including certainly Francesco di Giorgio Martini and Antonio and Giuliano da Sangallo, but also Leon Battista Alberti-experimentation began to discover the rules for tracing the new bastioned front. By the mid-sixteenth century, these rules were substantially defined.

The new front was designed according to a careful geometric analysis of artillery firing: shots for flanking defence, sketched in visual rays, defined the planimetric outlines of the fortified perimeters; rays also define the vertical section of the fortifications for défilement, or defilade, that is, the art of using features of the natural landscape or manmade land defences to protect the interior parts of a fortress. As Amelio Fara has pointed out, in the new fortified architecture, "its parts are in a relationship among themselves similar to that of the parts of a geometric system. The change introduced at one point has an impact on the integral whole, as in the geometric continuum of perspective" (Fara 1993: 11; my trans.). These new rules were extended beyond the fortified boundary, subjecting fortress compounds and even entire cities to those typical stellar plans that, inside, assured the functional reduction of the paths for the repositioning of troops and, outside, kept enemy artillery as far away as possible.

While closely related to functional parameters, the new military architecture was also the result of the more general Renaissance culture of architecture, for which geometry and proportion provided the basis for a new aesthetic conception as well as the link with the classical antiquity.

These experiences, which were at first genuinely and exclusively Italian, spread throughout Europe beginning in the second half of the sixteenth century, thanks to the circulation of treatises that became increasingly specialized with the passing of time: experiments tested on the battlefields found a place in theoretical models.

This laid the foundations for a progressively autonomous science-the science of war-, which found in geometry the scientific basis for predicting the effectiveness of a design.

Thus, in those years there came to be defined the figure of a specialist in warfare who applied his technical and theoretical knowledge to the solution of current problems. As Filippo Camerota writes, "shots of bombards affects the geometry of fortresses, require a proper understanding of the relationship between weight and range of the projectiles, impose the greatest precision in measurement and calculation, that is to force men of arms to acquire the mathematical basics necessary to the perfect management of armies" (Camerota 2002: 169; my trans.).

"Men of arms" needed to know arithmetic for the organization of soldiers; to have a working knowledge of geometry and stereometry for measuring surfaces, shapes and solids; to know mechanical sciences, for the proper use of war machines; to have practical experience with artillery; to know methods and tools for directly and indirectly surveying buildings, cities and territories; to know the techniques of representation; to have technical knowledge of military architecture, and to be capable of applying all this theoretical knowledge to any site regardless of condition (rocky or sandy, mountainous or in the plains, etc.).

Each of these skills describes some of the ways in which the relationship between mathematics and military architecture, the theme of this special issue, can be declined: geometry and architectural design of fortifications; applied mathematics in 
the early studies on ballistics; trigonometry, architectural survey and topography; geometry and representation of fortifications. These are therefore some of the keys with which the following papers deepen specific topics of research.

The first group of papers that make up this issue is entirely dedicated to theoretical aspects of military architecture. In "Alberti and Military Architecture in Transition", Marco Giorgio Bevilacqua and Kim Williams focus on Leon Battista Alberti's main treatise, De re aedificatoria, analyzing the parts where Alberti deals with military aspects, highlighting how the text represents a wonderful report of the state of fortifications in the first half of the fifteenth century, when artillery was coming into wider use. Shape, measure, relationship and proportion are the tools with which Alberti tries to give a first systemization to the medieval practices, laying the foundations for a new scientific treatment of the military architecture.

The two closely related papers that follow regard the origin and spread of military axonometry for the representation of fortifications. "Prospettiva Soldatesca: An Empirical Approach to the Representation of Military Architecture in the Early Modern Period”, by Miguel Ángel Alonso-Rodríguez and José Calvo-López, explores the topic from the origins of transoblique perspective in Antiquity and the Middle Ages, and then focuses on some of the most important scholars of military architecture from the end of the fifteenth to the first half of seventeenth century: Francesco di Giorgio Martini, Baldasare Peruzzi, Giovan Battista Zanchi, Bonaiuto Lorini, Hendrik Hondius up to Jean Du Breuil. "The Dissemination of Military Perspective through Fortification Treatises between the Sixteenth and Eighteenth Centuries", by Jorge Galindo Díaz, focuses on the most important specialists in the French and Spanish areas between the end of the sixteenth and the second half of the seventeenth century, including Bachot Ambroise, Claude Flamand, Jean Errard, Alonso de Cepeda y Adrada, Marqués de Leganés, Jean Du Breuil, and Blaise François Pagan.

The joint research of Josep Lluis i Ginovart, Josep M. Toldrà i Domingo, Gerard Fortuny Anguera, Agustí Costa Jover, Pau de Sola-Morales Serra, entitled "The Ellipse and the Oval in the Design of Spanish Military Defence in the Eighteenth Century", describes the persistence of U-shaped plan in the project of some Spanish fortifications in the eighteenth century; the study, substantiated by a careful metrological analysis, deals also with the verification of the geometric rootwhether oval or elliptical—of this planimetric form.

James McQuillan's “The Treatise on Fortification by Guarino Guarini” examines a little-studied aspect of the career of Guarino Guarini, with interesting references to Nicolas-François Blondel, Sébastian le Prestre de Vauban and Claude-François Milliet Dechales in the broader context of seventeenth-century military culture.

Laura Carlevaris's study, "Nicolas-François-Antoine de Chastillon: The Défilement of Fortifications at the Roots of Descriptive Geometry" sheds lights on the principles of défilement for tracing the vertical section of fortifications as described by Chastillon in the second half of the eighteenth century; the aim is to show how the tracing methods for défilement contributed to the genesis of modern descriptive geometry.

Adriana Rossi concludes the first part, with "Hellenic vestiges in the Bastioned Front of the late $1700 \mathrm{~s}$ ", her study on the treatise of the Jesuit Carlo Borgo, who in 
1777 proposed extremely complex layouts for fortifications based on Greek references. These layouts, which have never been applied, describe the apex of the theoretical discussion on the modern fortification.

The second group of papers presented here is dedicated to specific examples, organized in chronological order. In "Fortezza Vecchia in Livorno" Denise Ulivieri recalls the history of the old fortress of Livorno, one of the most important fortresses of the early sixteenth century, where Antonio and Giuliano da Sangallo experimented with the first examples of polygonal bastions; the study investigates the various phases of construction, from the medieval core up to the interventions of the sixteenth century.

The two contributions that follow introduce two members of the Antonelli family, Italian military architects, very active at the court of Spain between the sixteenth and seventeenth century. Sandro Parrinello and Silvia Bertacchi present "The Fort of Bernia by Giovanni Battista Antonelli", with original research about the only fortress he designed in Spain, which no longer exists but whose perimeter can still be discerned in aerial photographs. Based on a careful survey and rare documentary sources, the study critically analyzes the project, identifying the geometric root of the plan and the elevation. Olimpia Niglio, in "Geometry and Genius Loci: Battista Antonelli's Fortifications in Havana", focuses on the figure of the more famous Battista Antonelli (the younger brother of Giovanni Battista Antonelli), very active in the Spanish Caribbean at the end of the sixteenth century; in particular, Niglio analyzes two fortresses of his: the Castillo de los Tres Reyes del Morro and the Castillo San Salvador de la Punta in Havana, Cuba.

The evolution of Ottoman military architecture in the early sixteenth century is well described in "Early Modern Military Architecture in the Ottoman Empire" by H. Burcu Özgüven, who, through a careful reading of the formal and technical aspects of three exemplary fortresses, highlights the strong cultural exchange between the Ottoman Empire and the Italian Renaissance regarding the military techniques.

In "Are Vauban's Geometrical Principles Applied in the Petrovaradin Fortress?" Marija Obradović and Slobodan Mišić, in order to ascertain the paternity of the project, attributed to Sébastien Le Prestre de Vauban, propose a very careful study on the geometric genesis of the project at the various phases of expansion, in relation also to the theoretical principles expressed by the Count de Pagan and Vauban.

"The Citadel of Alessandria. Giuseppe Ignazio Bertola's Architectural Infraction of the Hexagon's Geometrical Regularity" by Amelio Fara concludes this issue. Fara is one of the most important scholars of military architecture in Europe; heartfelt thanks go to him for having accepted my invitation to publish a paper here. This paper is part of a wider research that the author has been carrying out for many years on the figure and the work of Italian military architect Bertola and on the School for Engineers in Torino in the late eighteenth century.

The research papers in this issue are complemented by four others works. In our Didactics column, Ahmed A. Elkhateeb and Esraa A. Elkhateeb present the final part of their series of article that have appeared in vol. 16: "Remarks on the Surface Area and Equality Conditions in Regular Forms Part IV: Pyramidal Forms". There 
are three book reviews in this issue. As guest editor of this issue, it was my pleasure to review Festungsbau: Geometrie, Technologie, Sublimierung, edited by Bettina Marten, Ulrich Reinisch and Michael Korey. Michela Rossi reviews The Italian Piazza Transformed: Parma in the Communal Age by Areli Marina. Last but not least, Kim Williams reviews Architecture, Astronomy and Sacred Landscape in Ancient Egypt by Giulio Magli.

Heartfelt thanks go to Kim Williams, $N N J$ co-editor in chief, for her irreplaceable guidance and support during the long phase of selection of the papers. My personal thanks go also to all the scholars who have dedicated part of their precious time to the review process of the papers: Paolo Bertoncini Sabatini, Roberto Castiglia, José Calvo-López, Giuseppe D’Acunto, Sylvie Duvernoy, Ralf Gebühr, Ewa Karwacka, Bettina Marten, Alessandro Merlo, Ana López Mozo, Alessandra Pagliano, Alexandra Paio, Marinella Pasquinucci, Enrique Rabasa, Clara Silvia Roero, Michela Rossi, Marta Salvatore, Margarida Tavares da Conceição and João Pedro Xavier.

\section{References}

Camerota, Filippo. 2002. Le scienze della guerra. In Storia d'Italia. Annali 18. Guerra e Pace, ed. Barberis Walter, 169-197. Torino: Einaudi.

Fara, Amelio. 1993. La città da guerra nell'Europa moderna. Torino: Einaudi.

Santoro, Rodo. 1996. Prefazione alla ristampa. In Dalle caverne ai rifugi blindati:trenta secoli di architettura militare, ed. Cassi Ramelli, Antonio, III-XXI. Bari: Adda.

Marco Giorgio Bevilacqua engineer, is an Assistant Professor of Architectural Representation at the University of Pisa, where he was graduated in 2003 and received a Ph.D. in "Sciences and techniques for the civil constructions" in 2008. His research interests are in the field of valorization of the historical architectural heritage, with particular attention to historical military architecture, architectural and urban survey and digital technologies for the communication of historical architectural heritage. He currently teaches Architectural Representation and Methodologies for Architectural surveying in the Master degree program of Building Engineering and Architecture. He has published several works and papers on his main research topics, presented conferences and lectures. Among his publications are Le mura di Pisa. Rafforzamenti, ammodernamenti e modificazioni dal XII al XIX secolo, co-authored with Cristina Salotti (Pisa: ETS, 2011); for the NNJ"The Conception of Ramparts in the Sixteenth Century: Architecture, 'Mathematics' and Urban Design" (NNJ9, 2 (2007), pp. 249-261), "The Turkish Baths in Elbasan: Architecture, Geometry and Wellbeing" with Roberto Castiglia (NNJ 10, 2(2008), pp. 307-321) and "Alexander Klein and the Existenzminimum: A 'Scientific' Approach to Design Techniques" (NNJ 13, 2 (2011), pp. 297-313). He is co-author with Kim Williams of "Leon Battista Alberti's Bombard Problem in Ludi matematici: Geometry and Warfare" (The Mathematical Intelligencer, 34, 8 (2013), pp. 27-38). 